\title{
Cardioembolic stroke in the setting of multiple left ventricular thrombi
}

\author{
Aleem Azal Ali $(1),{ }^{1}$ Dominika Zoltowska, ${ }^{2}$ Srinivasan Sattiraju, ${ }^{2}$ Emil Missov ${ }^{2}$
}

${ }^{1}$ Internal Medicine, University of Florida College of Medicine - Jacksonville, Jacksonville, Florida, USA

${ }^{2}$ Cardiology, University of Florida College of Medicine - Jacksonville, Jacksonville, Florida, USA

\section{Correspondence to}

Dr Aleem Azal Ali;

a.azal.ali@gmail.com

Accepted 22 April 2021
Check for updates

(C) BMJ Publishing Group Limited 2021. No commercial re-use. See rights and permissions. Published by BMJ.

To cite: Ali AA, Zoltowska D, Sattiraju $\mathrm{S}$, et al. BMJ Case Rep 2021;14:e242195. doi:10.1136/bcr-2021242195

\section{DESCRIPTION}

A 78-year-old man with a known ischaemic cardiomyopathy presented with hypoxaemic respiratory failure and undifferentiated shock. CT head revealed a large middle cerebral artery territory infarct. Transthoracic echocardiography revealed a depressed ejection fraction of $15 \%$ and multiple wall motion abnormalities. Multiple thrombi were identified in the left ventricular (LV) cavity with the largest attached to the anterior myocardial segment, measuring approximately $3.6 \times 2.0 \mathrm{~cm}$ (figures $1-2$, video 1 ). The patient expired shortly after admission to the intensive care unit.

LV thrombus formation can complicate ischaemic and non-ischaemic cardiomyopathies and result in systemic embolisation. A contemporary study found only 128 cases of LV thrombus out of 140636 echocardiograms reviewed. ${ }^{1}$ The presence of multiple LV thrombi is uncommon.

Virchow's triad describes the factors predisposing to thrombus formation: hypercoagulability, stasis and endothelial injury. The classic substrate for LV thrombus formation is a recent anterior myocardial infarction and an akinetic LV apical segment acting as a nidus for thrombus formation. ${ }^{2}$

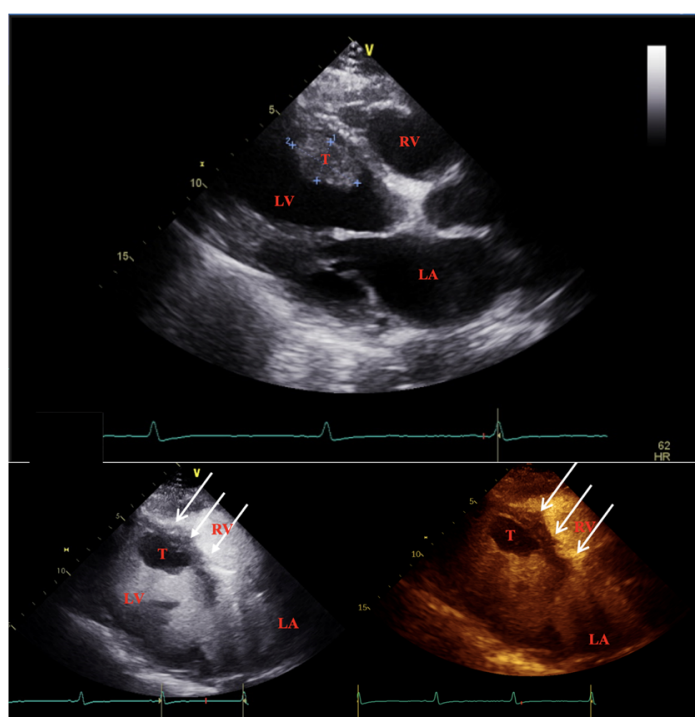

Figure 1 Echocardiogram of the LV in the parasternal long axis view showing a large filling defect consistent with left ventricular thrombus (arrowhead) attached to the interventricular septum (thin arrows). The blood pool is rendered white with the use of contrast for improved endocardial border definition. The large thrombus in the LV appears as a space occupying filling defect or negative contrast. $L A$, left atrium; $L V$, left ventricle; $R V$, right ventricle.

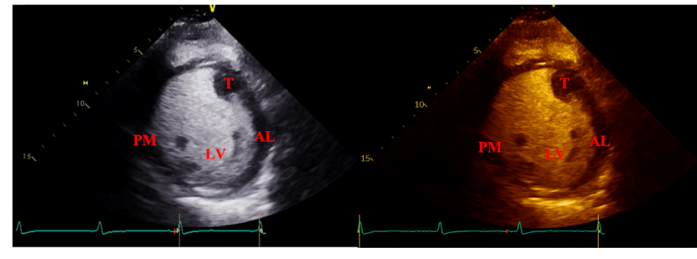

Figure 2 Echocardiogram of the left ventricle (LV) in the parasternal short axis view showing a large filling defect consistent with LV thrombus (arrowhead) at the 1 o'clock position. The anterolateral (AL) and posteromedial (PM) papillary muscles provide a visual comparison for the size of the LV thrombus relative to normal appearing anatomic structures in the LV.

An incidence of $1.6 \%$ of patients in a large STEMI (ST-segment elevated myocardial infarction) cohort was diagnosed with LV thrombus post-STEMI with the use of contrast in most of the studies. ${ }^{3}$ Additional risk factors include severe LV dysfunction, extensive regional wall motion abnormalities and LV aneurysm. ${ }^{4}$

A multimodality imaging approach for the diagnosis of intracardiac thrombi includes echocardiography and cardiac magnetic resonance imaging (CMR). Contrast-enhanced TTE is virtually diagnostic for LV thrombi. Contrast echocardiography in high-risk patients improves the detection of LV thrombus based on anatomic appearance..$^{5}$ Although clinically not absolutely necessary in classic cases, CMR imaging allows tissue characterisation and differentiation from other intracardiac masses. ${ }^{5}$

Major risk factors for systemic embolisation are thrombus mobility, protrusion into the LV cavity, visualisation on multiple views and

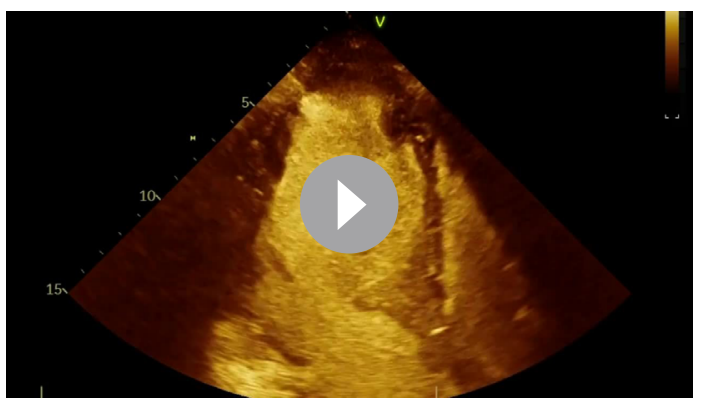

Video 1 Transthoracic echocardiography showing depressed left ventricular (LV) ejection fraction of 15\% with extensive wall motion abnormalities. Multiple thrombi were identified in the LV cavity. The largest was attached to the anterior myocardial segment and measured approximately $3.6 \times 2.0 \mathrm{~cm}$. 
adjacent segments of akinesis and hyperkinesis on echocardiography. ${ }^{67}$ Anticoagulant therapy with a vitamin $\mathrm{K}$ antagonist is recommended for at least 3 months to reduce embolic complications with a target international normalised ratio of 2.5. Alternative therapy includes the use of direct acting oral anticoagulants which have shown safety and efficacy for the treatment of LV thrombus. ${ }^{8}$ Selected high risk patients can be considered for surgical treatment when the embolic potential is very high or when mechanical circulatory support is required.

\section{Patient's perspective}

I know my uncle had heart problems; he just never went to the heart clinic. When they told me he had a massive stroke, I just knew he wouldn't have make it. I wish I checked on him more.

\section{Learning points}

- To highlight the uncommon finding of multiple left ventricular (LV) thrombi and review the classic substrate for LV thrombus formation.

- To highlight the multimodality imaging approach for diagnosis of intracardiac thrombi.

Acknowledgements Kevin Lui MD, Cardiology, University of Florida College of Medicine- Jacksonville.

Contributors AAA and DZ: acquisition of data and drafting of the manuscript. SS: critical revision of the manuscript. EM: drafting of the manuscript and critical revision of the manuscript.
Funding The authors have not declared a specific grant for this research from any funding agency in the public, commercial or not-for-profit sectors.

Competing interests None declared.

Patient consent for publication Obtained

Provenance and peer review Not commissioned; externally peer reviewed.

\section{ORCID iD}

Aleem Azal Ali http://orcid.org/0000-0003-4041-2301

\section{REFERENCES}

1 McCarthy CP, Murphy S, Venkateswaran RV, et al. Left ventricular thrombus. J Am Coll Cardiol 2019:73:2007-9.

2 Habash F, Vallurupalli S. Challenges in management of left ventricular thrombus. Ther Adv Cardiovasc Dis 2017; 11:203-13.

3 Mao TF, Bajwa A, Muskula P, et al. Incidence of left ventricular thrombus in patients with acute ST-segment elevation myocardial infarction treated with percutaneous coronary intervention. Am J Cardio/ 2018;121:27-31.

4 Jiang $Y-X$, Jing L-D, Jia Y-H. Clinical characteristics and risk factors of left ventricular thrombus after acute myocardial infarction: a matched case-control study. Chin Med J 2015:128:2415-9.

5 Weinsaft JW, Kim RJ, Ross M, et al. Contrast-Enhanced anatomic imaging as compared to contrast-enhanced tissue characterization for detection of left ventricular thrombus. JACC Cardiovasc Imaging 2009;2:969-79.

6 Visser CA, Kan G, Meltzer RS, et al. Embolic potential of left ventricular thrombus after myocardial infarction: a two-dimensional echocardiographic study of 119 patients. J Am Coll Cardiol 1985;5:1276-80.

7 Meltzer RS, Visser CA, Fuster V. Intracardiac thrombi and systemic embolization. Ann Intern Med 1986;104:689.

8 Fleddermann AM, Hayes $\mathrm{CH}$, Magalski A, et al. Efficacy of direct acting oral anticoagulants in treatment of left ventricular thrombus. Am J Cardiol 2019;124:367-72

9 Cousin E, Scholfield M, Faber C, et al. Treatment options for patients with mobile left ventricular thrombus and ventricular dysfunction: a case series. Heart Lung Vessel 2014;6:88-91.

Copyright 2021 BMJ Publishing Group. All rights reserved. For permission to reuse any of this content visit

https://www.bmj.com/company/products-services/rights-and-licensing/permissions/

BMJ Case Report Fellows may re-use this article for personal use and teaching without any further permission.

Become a Fellow of BMJ Case Reports today and you can:

- Submit as many cases as you like

- Enjoy fast sympathetic peer review and rapid publication of accepted articles

Access all the published articles

Re-use any of the published material for personal use and teaching without further permission

Customer Service

If you have any further queries about your subscription, please contact our customer services team on +44 (0) 2071111105 or via email at support@bmj.com.

Visit casereports.bmj.com for more articles like this and to become a Fellow 